Arab Univ. J. Agric. Sci., Ain Shams Univ., Cairo, 13(3), 963 - 977, 2005

\title{
EFFICIENCY OF CERTAIN INSECTICIDES ON WHITEFLY LEAF CURL VIRUS AND THEIR RESIDUES IN TOMATO FRUITS
}

[65]

\author{
Soad, A. Ibrahim ${ }^{1}$; Nadra, M. Elias ${ }^{2}$; Ola, M.Y. Emara²; \\ Fathy E. El-Adl ${ }^{1}$ and M.KH. El-Sheemy ${ }^{2}$
}

\begin{abstract}
The work was conducted to clarify the efficiency of certain insecticides on the population of whitefly $B$. tabaci and incidence of yellow leaf curl virus (TYLCV) in tomato field. The experiment was carried out during Nili plantation of two successive seasons at El-Fayoum governorate. The obtained data showed that the alternate use of etofenprox /thiamethoxam; imidacloprid/ thiamethoxam; acetamiprid/ etofenprox; single continuous application of etofenprox; etofenprox / imidacloprid; acetamiprid/ imidacloprid; thiamethoxam/ acetamiprid; imidacloprid; thiamethoxam and acetamiprid gave excellent initial mortality over $90 \%$ on the adult stage of $B$. tabaci and incidence of tomato yellow leaf curl virus without significant differences between treatments. Thimethoxam as soil drench proved to be the most effective insecticide against adult and immature stages of whitefly, while acetamiprid achieved the lowest mortality for these two stages as well as short residual mortality. On the other hand, alternation of etofenprox / imidacloprid showed the highest initial mortality on nymphs. Residue levels in tomato fruits were also investigated at 30, 45 and 60 days after application of tested insecticides. For imidacloprid residues were found in amounts nearly above maximum residue levels MRLs 30 days while degraded to amounts below MRL by the progression of time to 45 and 60 days after application. Application of imidacloprid in alternate spray program with thiamethoxam; etofenprox; acetamiprid resulted in residues below MRL at the 3 preharvest intervals. Acetamiprid when used at the recommended rate showed the residue of $0.36 \mathrm{mg} / \mathrm{kg}$ at early season and then decreased to $0.08 \mathrm{mg} / \mathrm{kg}$ at late season. Alternate use of acetamiprid with thiamethoxam; etofenprox or imidacloprid reduce MRLs in tomato fruits. The successive applications of etofenprox alone at the recommended rate resulted in residues above MRL after 30 and 45 days and approximately near MRL at 60 days. On the other hand, the half rate in alternative use with imidacloprid; acetamiprid or thiamethoxam showed residues below MRL at all sampling intervals. Thiamethoxam when used in single successive applications gave residues of $2.5,1.9$ and $1.5 \mathrm{mg} / \mathrm{kg}$ at the 3 preharvest intervals, respectively.
\end{abstract}

1- Plant protection Res. Institute, Agric.Res. Center, Dokki, Egypt

2- Central Agricultural Pesticides Laboratory, Dokki, Giza; Egypt

(Received May 25, 2005)

(Accepted June 13, 2005) 
Soad; Nadra; Ola; Fathy and El-Sheemy

Key words: Insecticides, Tomato fruits, Residues, HPLC, GC, (Gas chromctography) 
Arab Univ. J. Agric. Sci., Ain Shams Univ., Cairo, 13(3), 963 - 977, 2005

\section{INTRODUCTION}

Tomato, Lycopersicum esculentum Mill is one of the main important vegetable crops in Egypt and in the world. The whitefly, Bemisia tabaci (Genn.) (Hemiptera Aleyrodidae) is considered as the major insect pest attacking tomato, especially at Nili plantation in Egypt. It causes direct damage to tomato plants by sucking the plant juice in addition to indirect damage by transmitting tomato yellow leaf curl virus (TYLCV) (Shaheen, 1976). It causes severe loss of tomato production that reaches 90\% (Banerjee and Kalloo, 1987). The highly reduction of tomato yield inducing by TYLCV depends on several factors especially the age of plants at time of infestation (Turkoglur, 1978) and planting season (Mazyd et al 1969). The usage of insecticides to control whitefly must give a high insect mortality with low mammalian toxicity within the first two months after plantation (Omar et al 1996) and (ElBessomy et al 1997).

According to the Ministry of agriculture of Egypt, acetamiprid, imidacloprid, thiamethoxan and etofenprox insecticides are recommended for use against insects infesting vegetables, lettuces, cabbages, tomato etc. These insecticides are characterized by high control efficacy, low toxicity and short residual activity. The necessity of successive, consecutive and repeated pesticide applications may lead to the accumulation of their residues to levels considerably higher than the maximum residue levels (MRLs) accepted by JMPR. Accordingly the residue levels persisting on tomato fruits should be evaluated to assure that they are not exceeded the MRLs and establish preharvest intervals (PHI) (CAC/PR, 1999).

The present investigation aimed to throw light on the efficacy of insecticides applied in single and alternating applications on tomato plants against adult and nymphs of whitefly and incidence of tomato yellow leaf curl virus. Also the levels of applied insecticide residues in tomato fruits and the pre-harvest intervals (PHI) for safely consumption were determined.

\section{MATERIAL AND METHODS}

Experiments were conducted to study the efficacy of certain insecticides which are used either as single application for several times or by alternating applications against adults and nymphs of whitefly, Bemisia tabaci (Genn.) and of tomato yellow leaf curl virus. In addition, the residue levels of tested insecticides in harvested tomato fruits were determined in order to evaluate the preharvest intervals (PHI) for safety consumption.

\section{Experimental design}

The seeds of Al-Kods E448 tomato variety were planted in a good coverage greenhouse nursery on June $22^{\text {th }}$ Nili

1- Plant protection Res. Institute, Agric.Res. Center, Dokki, Egypt

2- Central Agricultural Pesticides Laboratory, Dokki, Giza; Egypt

(Received May 25, 2005)

(Accepted June 13, 2005) 
plantation and transplanted in the open field on July $22^{\text {th }}$ at 2002 and 2003 seasons at El-mandra village, El-Fayoum governorate. An area of one feddan was cultivated with Al-Kods E448 variety of tomato and divided into plots about $80 \mathrm{~m}^{2}$ each. The plots received the normal agricultural practices except insecticide treatments. Each treatment and the check were randomly replicated four times in completely randomized block.

\section{Insecticides, Application and Sampling}

\section{a) The following insecticides were used}

Etofenprox: (2-(4- ethoxyphenyl) -2methyl propyl-3-phenoxybenzyl ether) selected trade name "Trebon" $30 \%$ EC produced by (Minsui Toatus) was used as foliar application at $250 \mathrm{ml} /$ Fed.

Imidacloprid: (1-(6-chloropyridylmethyl) -N-nitroimidazolidin-2-ylide neamine) selected trade name "Admire" 20\% SC produced by (Bayer) was used as foliar application at $500 \mathrm{ml} / \mathrm{Fed}$.

Acetamiprid: [( $\mathrm{N}^{1}$ [(6-chloro-3-pyridyl) methyl] $\quad-\mathrm{N}^{2}$-cyano- $\mathrm{N}^{1}$-methyl acetamidine) selected trade name "Mospilan" 20\% SP produced by (Nippon Soda) was used as foliar application at $100 \mathrm{ml} / \mathrm{Fed}$.

Thiamethoxam: (3-(2-chloro-1,3-thiazol5-ylmethyl)-5-methyl-1,3,5oxadiazinon-4-ylidene nitro selected trade name "Actra" 25\% WG Produced by (Novartis) was used as soil drench at $350 \mathrm{~g} / \mathrm{Fed}$.

\section{b) The following sequence applications of pesticide treatments were carried}

\section{out into three times for each component}

etofenprox / imidacloprid.

etofeprox /acetamiprid.

etofenprox/thiamethoxam.

imidacloprid /thiamethoxam.

imidacloprid / acetamiprid .

thiamethoxam / acetamiprid.

The insecticides etofenprox (Trebon), imidacloprid (Admire) and acetamiprid (Mospilan) were sprayed as foliar spray six times at regular intervals of seven days, and three times through the alternate sequential programme by using knapsack sprayers. Sprays started one week after transplantation. Thiamethoxam (Actra) was used as soil drench into 3 times at 14 day intervals, started one week after transplanting. The check plot was sprayed with water. The population of adult stage of whitefly on treated foliage was counted just before spray and then after 1, 3, 5 and 7 days. 75 leaves representing the three levels of the plant were replicated. The numbers of adults were examined in soil drench treatment and were counted before and at $1,3,5,7,10,12$ and 14 days after treatment. For each treatment a sample of 300 leaves was randomly picked up from the three plant levels. Each replicate was represented by 75 leaves, kept in paper bag and directly transferred to the laboratory for examination by the aid of stereo-microscope. In addition, the nymphs of whitefly were counted and recorded before and at 2, 5 and 7 days from each spray in foliar spray treatments. While in the treatment of soil drench, the nymphs were counted before and at 2,5,7,10,12 and 14 days after treatment. 
966

\section{Insecticides efficiency on whitefly leaf curl virus}

After 30 and 60 days from transplantation the symptoms of tomato yellow leaf curl virus (TYLCV) on tomato plants were examined and recorded in the field. The obtained data were analyzed by using Henderson and Tilton method (1955) and Chi square Gomez and Gomez (1984). Representative samples of tomato fruits were randomly picked up at harvest time at three intervals of 30,45 and 60 days after the last insecticide application, kept in polyethylene bags at $-20^{\circ} \mathrm{C}$ for residue analysis.

\section{Residue Analysis of insecticides}

3.1. Acetamiprid: Residues were extracted according to the method of (Masanori and Takeshi, 1994). Tomato sub samples of $20 \mathrm{~g}$ were homogenized with $100 \mathrm{ml}$ methanol, the homogenate was filtered. The filtrate was shaken with $10 \mathrm{ml}$ saturated sodium chloride solution and $100 \mathrm{ml}$ hexane, the hexane layer was discarded. The aqueous methanol was extracted with $100 \mathrm{ml}$ dichloromethane. The dichloromethane layer was dried over anhydrous sodium sulfate. The extract was concentrated to near dryness under reduced pressure; the residue was dissolved in the proper volume of methanol for clean up by thin layer chromatography (TLC) using eluting solvent of methanol+ water $(8+2, \mathrm{v} / \mathrm{v})$. The residue was dissolved in the proper volume of methanol for GC analysis.

3.2. Imidacloprid: Residues were extracted from the collected samples according to the method of (Blass, 1990). A $20 \mathrm{~g}$ of the samples were homogenized with $100 \mathrm{ml}$ acetonitrile. The extract was filtered and then evaporated under reduced pressure. The aqueous remained layer was shaken with $10 \mathrm{ml}$ of saturated sodium chloride solution and $100 \mathrm{ml}$ hexane, the hexane layer was discarded. The aqueous phase was reextracted with $100 \mathrm{ml}$ of dichloromethane; the lower dichloromethane layer was dried over anhydrous sodium sulfate, then concentrated near dryness under reduced pressure. Residues were cleaned up through a florisil column, which was eluted with acetonitrile. The eluate was concentrated just to dryness and the residue was dissolved in the proper volume of methanol for HPLC analysis.

3.3. Etofenprox: Residues were extracted and cleaned up according the method of (Takeshi and Kazuhiro, 1985). $20 \mathrm{gm}$ of the analytical samples were mixed with $100 \mathrm{ml}$ acetone and homogenized, the extract was filtered and then concentrated under reduced pressure. $10 \mathrm{ml}$ of saturated sodium chloride was added and well mixed. The aqueous layer was extracted with $100 \mathrm{ml}$ hexane. The hexane extract was dehydrated over anhydrous sodium sulfate, then concentrated near dryness using rotary evaporator under reduced pressure. Clean up of residue was done trough a florisil column chromatograph, then eluted with $70 \mathrm{ml}$ of hexane:ethyl ether $(95: 5 \mathrm{v} / \mathrm{v})$. The eluate was concentrated near dryness under reduced pressure. The residue was dissolved in the proper volume of methanol for GC analysis.

3.4. Thiamethoxam: Residues were extracted according to (Nasr, et al 2003). $20 \mathrm{~g}$ of the prepared sample was homogenized with $100 \mathrm{ml}$ methanol, the homogenate was filtered. The filtrate was successively shaked with 3 x $50 \mathrm{ml}$ of methylene chloride after adding $10 \mathrm{ml}$ of 
saturated sodium chloride solution. The methylene chloride phase was dried over anhydrous sodium sulfate and then evaporated near dryness under reduced pressure. The residue was dissolved in 5 $\mathrm{ml}$ methanol and cleaned up according to (Johnson, 1963) using coagulating solution (0.5 $\mathrm{g}$ ammonium chloride and $1 \mathrm{ml} 85 \%$ orthoposphoric acid solution in $400 \mathrm{ml}$ distilled water). The residue was mixed with $10 \mathrm{ml}$ of cooled freshly prepared coagulating solution and the contents were quantitavely transferred and filtered through a chromatographic column of $2.5 \mathrm{~cm}$ diameter packed with a $5 \mathrm{~cm}$ layer of Hyflo super cell. This washing was repeated three times using 5 $\mathrm{ml}$ methanol and $10 \mathrm{ml}$ coagulating solution each time. The filtrate was collected and extracted with $3 \times 50 \mathrm{ml}$ chloroform. The chloroform extracts were evaporated just to dryness under vacuum. The residues were dissolved in the proper volume for GC analysis.

\section{Chromatographic Techniques}

Hewlett-Packard gas chromatograph with flame ionization detector, fitted with packed column (3\% OV101) on chromosorb WHP 80/100 mech, 120 feet was used. Operating conditions for acetamiprid residues: Oven $\mathrm{t}^{\circ}$ : $220^{\circ} \mathrm{C}$, injection port $\mathrm{t}^{\circ}: 275^{\circ} \mathrm{C}$ and detector: 300 ${ }^{\circ} \mathrm{C}$, the retention time of acetamiprid is about $1.95 \mathrm{~min}$. Operating conditions for etofenprox residues: oven $\mathrm{t}^{\circ}$ : $220{ }^{\circ} \mathrm{C}$, injection port $\mathrm{t}^{\circ} 250{ }^{\circ} \mathrm{C}$ and detector $\mathrm{t}^{\circ}$ : $275^{\circ} \mathrm{C}$. The retention time of etofenprox is about $3.661 \mathrm{~min}$. Operating conditions for thiamethoxam residues: Oven $t^{\circ}$ $175^{\circ} \mathrm{C}$, injection port $t^{\circ} 255^{\circ} \mathrm{C}$ and detector $\mathrm{t}^{\circ} 285^{\circ} \mathrm{C}$. The retention time of thiamethoxam is about $3.005 \mathrm{~min}$. High performance liquid chromatograph equipped with a photodiode array detector using an inertsil ODS-column $(150 \times 4.6 \mathrm{~mm}$ i.d.) with a gradient system of acetonitrile: water (60/40) (v/v) as the mobile phase at a flow rate of $1.0 \mathrm{ml} / \mathrm{min}$ : The retention time recorded for imidacloprid is about $3.027 \mathrm{~min}$.

\section{Recovery and limit of detection (LOD)}

The recoveries were determined using fortifying samples in which defined amounts of active ingredients are added to blank samples prior the extraction. The imidacloprid recovery percentage mean was $112.7 \%$, for acetamiprid $90 \%$, for thiamethoxam $89.2 \%$ and for etofenprox $72 \%$. Pesticide residues are calculated as $\mathrm{ppm}(\mathrm{mg} / \mathrm{kg})$ proportionate to the mean sample response from the duplicate injections to the mean standard response. At last one untreated sample must be analyzed alongside any set of samples, this to ensure that no contamination of the samples occurred prior to, or during the analysis. The mean percentage recovery value obtained Table (3) is used to correct residues determined in the samples.

\section{RESULTS AND DISCUSSION}

\section{Initial and residual efficiency against adult stage of whitefly}

As for initial efficiency of data in Table (1) showed that all tested insecticides achieved high initial corrected mortality percent over $90 \%$ on the adult stages of whitefly during the two seasons. The sequential treatments by alternative etofenprox / thiamethoxam pesticides showed the highest initial corrected mortality percentage at 94.6 
Insecticides efficiency on whitefly leaf curl virus

and $93.9 \%$ in 2002 and 2003 seasons respectively. The single application of acetamiprid caused $90.7 \%$ and $90.2 \%$ at the same two seasons respectively. These results are in agreement with those of (Farrag et al 1994). They reported that etofenprox gave $90.98 \%$ mortality after one day on adult stage of $B$. tabaci infesting cabbage plants. Statistical analysis by using Chi-square parameter showed insignificant differences between the tested insecticides during the two seasons.

As for Residual activity data in the same table indicate that thiamethoxam gave the highest residual mortality after 
Arab Univ. J. Agric. Sci., Ain Shams Univ., Cairo, 13(3), 963 - 977, 2005

1- Plant protection Res. Institute, Agric.Res. Center, Dokki, Egypt

2- Central Agricultural Pesticides Laboratory, Dokki, Giza; Egypt (Received May 25, 2005)

(Accepted June 13, 2005) 
Arab Univ. J. Agric. Sci., Ain Shams Univ., Cairo, 13(3), 963 - 977, 2005

3-14 days on adult stage of whitefly reaching $90.2 \%$ and $90.1 \%$ in 2002 and 2003 seasons respectively. On the other hand, acetamiprid showed the lowest residual corrected mortality percentage of $73.8 \%$ and $73.6 \%$ in the $1^{\text {st }}$ and $2^{\text {nd }}$ seasons respectively. (El-Bessomy et al 1997) stated that imidacloprid gave excellent control on the adult of whitefly infesting tomato plants. Statistical analysis showed that tested insecticides could be grouped into two categories according to their efficiency on whitefly adults during the two seasons. The $1^{\text {st }}$ category included the most effective insecticides being thiamethoxam, imidacloprid / thiamethoxam, etofenprox / thiamethoxam, imidacloprid, etofenprox / acetamiprid, acetamiprid / imidacloprid and acetamiprid / etofenprox while the $2^{\text {nd }}$ category included acetamiprid.

\section{Initial and residual efficiency on immature stages}

As for initial activity of data in Table (2) showed that sequential applications of etofenprox /imidacloprid, imidacloprid and etofenprox caused great mortality percent over $90 \%$ against immature stages of whitefly after $24 \mathrm{hrs}$. On the other hand thiamethoxam as soil drench gave 63.17 and $62.9 \%$ mortality after 48 hrs in 2002 and 2003 seasons respectively. Statistical analysis showed significant differences between the tested insecticides. Insecticides could be grouped into three categories based on their initial activities. The $1^{\text {st }}$ group included etofenprox/ imidacloprid, imidacloprid, etofenprox, acetamiprid/ imidacloprid, acetamiprid / etofenprox and acetamiprid. The $2^{\text {nd }}$ group represented imidacloprid / thiamethoxam, etofenprox/ thiamethoxam, and thiamethoxam/acetamiprid while the $3^{\text {rd }}$ group included thiamethoxam. (ElBessomy et al 1997) reported that imidacloprid gave $91.49 \%$ mortality on immature stages of whitefly infesting tomato plants.

As for Residual activity data in the same table showed that thiamethoxam achieved the highest mortality reaching $90.8 \%$ and $90.6 \%$ in 2002 and 2003 seasons respectively. Sequential treatments showed that imidacloprid / thiamethoxam gave the highest corrected mortality percentage into 89.5 and $89.9 \%$ in the $1^{\text {st }}$ and $2^{\text {nd }}$ seasons respectively. On the contrary acetamiprid showed the least mortality percent of $64.1 \%$ and $63.9 \%$ were recorded during the same seasons respectively. Statistical analysis showed significant differences between the tested insecticides during the two seasons. Insecticides could be grouped into two categories according to their efficiency in controlling immature stages of B. tabaci. The $1^{\text {st }}$ category included thiamethoxam, imidacloprid / thiamethoxam, imidacloprid, etofenprox / imidacloprid, etofenprox / thiamethoxam, imidacloprid, etofenprox / imidacloprid, thiamethoxam / acetamiprid and acetamiprid / imidacloprid, while the $2^{\text {nd }}$ category included etofenprox,

1- Plant protection Res. Institute, Agric.Res. Center, Dokki, Egypt

2- Central Agricultural Pesticides Laboratory, Dokki, Giza; Egypt

(Received May 25, 2005)

(Accepted June 13, 2005) 
acetamiprid / etofenprox and acetamiprid.

\section{Effect on the incidence of virus symptoms}

Data in Table (1) showed that the tested insecticides reduced significantly the number of plants with virus symptoms compared with the untreated ones. Etofenprox / thiamethoxam sequences gave the lowest incidence of virus symptoms amounted $3.9 \%$ and $3.8 \%$ in 2002 
Arab Univ. J. Agric. Sci., Ain Shams Univ., Cairo, 13(3), 963 - 977, 2005

1- Plant protection Res. Institute, Agric.Res. Center, Dokki, Egypt

2- Central Agricultural Pesticides Laboratory, Dokki, Giza; Egypt (Received May 25, 2005)

(Accepted June 13, 2005) 
Table 3. Recovery \% of the tested insecticides from tomato fortified at different levels

\begin{tabular}{|c|c|c|}
\hline Insecticides used & $\begin{array}{c}\text { No of recoveries } \\
\text { at } \\
\text { specified level in } \\
\mathrm{mg} / \mathrm{kg}\end{array}$ & $\begin{array}{c}\text { Recoveries \% } \\
\pm \mathrm{SD}\end{array}$ \\
\hline Imidacloprid & $\begin{array}{c}3 \times 0.01 \\
3 \times 0.05 \\
3 \times 0.1 \\
\end{array}$ & $\begin{array}{l}120.4 \pm 3.5 \\
105.9 \pm 4.7 \\
111.8 \pm 5.2\end{array}$ \\
\hline Mean & & 112.7 \\
\hline Acetamiprid & $\begin{array}{c}3 \times 0.01 \\
3 \times 0.05 \\
3 \times 0.1\end{array}$ & $\begin{array}{l}92.5 \pm 3.4 \\
87.4 \pm 6.5 \\
90.1 \pm 7.5 \\
\end{array}$ \\
\hline Mean & & 90.0 \\
\hline Thiamethoxam & $\begin{array}{c}3 \times 0.01 \\
3 \times 0.05 \\
3 \times 0.1\end{array}$ & $\begin{array}{l}92.6 \pm 1.2 \\
90.5 \pm 0.7 \\
84.5+6.8 \\
\end{array}$ \\
\hline Mean & & 89.2 \\
\hline Etofenprox & $\begin{array}{c}3 \times 0.05 \\
3 \times 0.01 \\
3 \times 0.1\end{array}$ & $\begin{array}{c}73.4 \pm 0.45 \\
70,6 \pm 4.3 \\
70.0 \pm 3.1\end{array}$ \\
\hline Mean & & 72.0 \\
\hline
\end{tabular}

and 2003 seasons respectively. Statistical analysis showed no significant difference between the tested insecticides. Such results are in agreement with that obtained by (Hayder et al 1995) who reported that there are interrelation between whitefly and the incidence of tomato yellow leaf curl virus.

\section{Determination of residue levels}

Data in Table (4) indicated that imidacloprid residue levels in tomato fruits which were treated by the recommended rate of foliar application as single and successive application were found at MRLs after 30 days (early season) and below the limit after 45 and
60 days (mid and late seasons). The MRLs which were established by different countries like Brazil, Portugal and Turkey is $0.5 \mathrm{mg} / \mathrm{kg} \mathrm{CAC/PR} 2002$. (Draeger et al 1989) investigated the metabolism of [C 14 -methylene $]$ imidacloprid in tomato, apples and potatoes after spray application with solution of imidacloprid $25 \% \mathrm{WP}$ at a rate of $250 \mathrm{~g}$ ai /ha. The total radiolabelled residue levels decreased from $1.01 \mathrm{ppm}$ after 4 days of application to be 0.84 and $0.85 \mathrm{ppm}$ after 7 and 14 days respectively.

But, residues of 0.64 ppm was detected in the post harvest samples (21 days). The easy way to avoid residues above MRLs is to reduce insecticide rate, 
Arab Univ. J. Agric. Sci., Ain Shams Univ., Cairo, 13(3), 963 - 977, 2005

by spraying plants every 7 days with

either imidacloprid or acetamiprid in alternation. By decreasing the recommended

1- Plant protection Res. Institute, Agric.Res. Center, Dokki, Egypt

2- Central Agricultural Pesticides Laboratory, Dokki, Giza; Egypt

(Received May 25, 2005)

(Accepted June 13, 2005) 
Arab Univ. J. Agric. Sci., Ain Shams Univ., Cairo, 13(3), 963 - 977, 2005

Table 4. Residues of acetamiprid, imidacloprid, etofenprox and thiamethoxam in tomatoes in single, successive and alternating applications

\begin{tabular}{|lccc|}
\hline \multicolumn{1}{|c}{ Compounds used } & \multicolumn{3}{c|}{ Residues detected in $\mathrm{mg} / \mathrm{kg}$ at different intervals } \\
after last application \\
\hline Imidacloprid & 30 days & 45 days & 60 days \\
Acetamiprid & $0.65 \pm 0.7$ & $0.37 \pm 0.36$ & $0.17 \pm 0.06$ \\
Thiamethoxam & $0.35 \pm 0.1$ & $0.24 \pm 0.01$ & $0.08 \pm 0.3$ \\
Etofenprox & $2.5 \pm 0.5$ & $1.9 \pm 0.6$ & $1.50 \pm 0.15$ \\
Imidacloprid/Etofenprox & $1.9 \pm 0.8$ & $1.7 \pm 0.5$ & $0.53 \pm 0.3$ \\
& $0.27 \pm 0.05$ & $0.20 \pm 0.05$ & $0.08 \pm 0.02$ \\
Imidacloprid/Thiamethoxam & $(0.8 \pm 0.4)$ & $(0.75 \pm 0.25)$ & $(0.35 \pm 0.11)$ \\
& $0.29 \pm 0.07$ & $0.15 \pm 0.03$ & $0.09 \pm 0.04$ \\
Acetamiprid/ thiamethoxam & $(1.2 \pm 0.7)$ & $(0.8 \pm 0.4)$ & $(0.5 \pm 0.2)$ \\
& $0.20 \pm 0.5$ & $0.11 \pm 0.7$ & $0.05 \pm 0.6$ \\
Acetamiprid/ Etofenprox & $(0.25 \pm 0.5)$ & $(0.18 \pm 0.6)$ & $(0.1 \pm 0.02)$ \\
& $0.19 \pm 0.02$ & $0.15 \pm 0.04$ & $0.08 \pm 0.03$ \\
Etofenprox/ thiamethoxam & $(0.9 \pm 0.41)$ & $(0.72 \pm 0.11)$ & $(0.25 \pm 0.05)$ \\
& $1.11 \pm 0.4$ & $0.91 \pm 0.7$ & $0.71 \pm 0.1$ \\
Imidacloprid/Acetamiprid & $(0.21 \pm 0.5)$ & $(0.15 \pm 0.08)$ & $(0.07 \pm 0.02)$ \\
& $0.32 \pm 0.4$ & $0.25 \pm 0.3$ & $0.1 \pm 0.03$ \\
& $(0.22 \pm 0.02)$ & $(0.12 \pm 0.06)$ & $(0.05 \pm 0.01)$ \\
\hline
\end{tabular}

Results are presented as mean \pm SD.

Residues of alternating compounds are listed between bracktes.

rate of imidacloprid to the half rate, residue levels in tomatoes (Table, 4 ) were found under MRLs at early, mid and late seasons. Similar MRLs reduction were recorded for alternate sequential treatments of imidacloprid or etofenprox and imidacloprid or thiamethoxam. (Draeger et al 1989) investigated the metabolism of imidacloprid as foliar application in tomatoes and apples, acropetal translocation was demonstrated 14 days after application, radioactivity in fruits accounted for 0.003 to $0.006 \mathrm{mg} / \mathrm{kg}$ parent compound equivalents also 11 metabolites were identified by TLC and H-NMR and mass spectrometry. As for acetamiprid $20 \%$ SP, data in the same table indicated that residue levels in

1- Plant protection Res. Institute, Agric.Res. Center, Dokki, Egypt

2- Central Agricultural Pesticides Laboratory, Dokki, Giza; Egypt

(Received May 25, 2005)

(Accepted June 13, 2005) 
Arab Univ. J. Agric. Sci., Ain Shams Univ., Cairo, 13(3), 963 - 977, 2005

tomatoes that received the recommended rate in single and successive applications, were found relatively low $(0.35 \mathrm{mg} / \mathrm{kg})$ at early season, while decreased to 0.08 $\mathrm{mg} / \mathrm{kg}$ at late season. The high disappearance rate of acetamiprid could be referred to its high degradation rate.

(CAC/PR, 2002).

Using half rate of application with either acetamiprid or imidacloprid in alternation, acetamiprid or etofenprox in alternation and acetamiprid or thiamethoxam resulted in low MRLs of acetamiprid. No MRL was established in Codex Alimentarious Committees. For etofenprox $30 \% \mathrm{EC}$ as non ester pyrethroid insecticide when used by foliar application in single and successive applications on tomato plants showed levels of $1.9,1.7$ and $0.53 \mathrm{mg} / \mathrm{kg}$ at 30 , 45 and 60 days after last application.

Residue levels were above MRLs after 30 and 45 days compared with those established by different countries i.e. Japan, Spain and Italy is $0.5 \mathrm{mg} / \mathrm{kg}$ (Tomoda, 1985a and b) Half rate of this insecticide resulted in residues below MRL at the three considered intervals. In the case of thiamethoxam $25 \% \mathrm{WG}$ a new generation neonicotinoid was applied as soil drench at the recommended rate used in 3 single successive applications/ season and into 14 day intervals. Tomato fruits picked at early, mid and late season showed residue levels $2.5,1.9$ and $1.5 \mathrm{mg} / \mathrm{kg}$ respectively. The alternate use of thiamethoxam or imidacloprid, thiamethoxam or accetamiprid and thiamethoxam or etofenprox resulted in thiamethoxam residues decline with time elapsed, reaching $0.07 \mathrm{mg} / \mathrm{kg}$ with etofenprox or thiamethoxam in alternation. Maximum residue level (MRL) of thiamethoxam did not exist in Codex Alimentarious Committees.

\section{REFERENCES}

Banerjee, M.K. and G. Kalloo (1987). Sources and inheritance to leaf curl virus in Lycopercicum. Theor. Appl. Genet., 73: 707-710.

Blass, W. (1990). Method for the determination of imidacloprid residues in plant materials using HPLC and UV detection. Bayer AG, Crop Protec. Res., Chemical Product Development and Environ. Biology Institute for Product Information and Residue Analysis. (Technical Report, Method 00171, 1990).

Codex Alimentarius Committes for Pesticide Residue (CAC/PR) (1999). Guide to Codex Recommendation Concerning Pesticide Residues. Maximum limit for pesticide residues. FAO/WHO. Codex Alimentarius Committes for Pesticide Residue (CAC/PR) (2002). Guide to Codex Recommendation Concerning Pesticide Residues. Maximum limit for pesticide residues. FAO/WHO.

Draeger, W.; G. Bernatsh and A. Brauner (1989). Metabolism in tomatoes. Bayer AG.Report No PF 3257.

1- Plant protection Res. Institute, Agric.Res. Center, Dokki, Egypt

2- Central Agricultural Pesticides Laboratory, Dokki, Giza; Egypt

(Received May 25, 2005)

(Accepted June 13, 2005) 
16

Soad; Nadra; Ola; Fathy and El-Sheemy

Date 1989-10-12. (Ammended: 1991-0508).

El-Bessomy, M.A.E.; M.H.M. El-

Khawalka; H.I.H. Omar and H.M. ElMagraby (1997). Effect of the fungal insecticide biofly compared with chemical insecticide in controlling different stages of whitefly Bemsia. tabaci (Genn.) and its related virus. Egypt. Agric. Res. 75 (4) : 915 -921. Farrag, R.M.; Fawzia, K. Kotb and Neima, I. Noussier (1994). Factors affecting the chemical control of the whitefly, Bemisia tabaci on cabbage plants. J. Agric. Res. 39(3): 307-316. Gomez., K.A. and A.A. Gomez (1984). Statistical Procedures for Agricultural Research $2^{\text {nd }}$. Ed. John Wiley and Sons. New York, U.S.A.

Hayder, M.F.; H. Abd El-Wahab,; A. Mona Ahmed and Shahinaz, E. ElDeeb (1995). Effect of tomato planting dates during Nili plantation on Bemisia tabaci (Genn.) population and its relation to TYLCV as a limiting factor of crop production. $1^{\text {st }}$ Int. Conf. of Pest Control. Mansoura, Egypt, pp. 333-338.

Henderson, C.F. and W.W. Tilton (1955). Test with acaricides against the brown wheat mite. J. Econ. Ent. 48: 157161.

Johnson, D.P. (1963). Determination of seven insecticides in fruits and vegetables. J.A.O.A.C.: 234-238.

Masanori, Tokieda and Takeshi

Gomyo (1994). Residue Analystical

Method of Insecticide N-25 in Crops.

Parent method. Rotary report No.EC-521, May 23, 1994. Nippon Soda Co., LTD.

Tokyo, Japan.

Mazyd, H.M.; K.R. Stino; A.A.

Radwan, and Nour El-Din (1969).

Effect of tobacco mosaic virus on growth chemical constituents and yield of tomato plants. Agric. Res. Rev., Cairo, 74: 87-

90.

Nasr, I.N.; Nevein, S. Ahmed and M.M. Al-Maz (2003). Effect of boiling and some environmental factors of penconazole fungicide on vine leaves. Annals Agric. Sci., Ain Shams Univ., Cairo 48(1): 365-372. 
Omar, H.I.H.; H.M. El-Maghraby; M.H.M. El-Khawalka and M.A. ElBessomy (1996). Effect of different rates of the antifeeder pyme- trozine on various stages of the whitefly Bemisia tabaci (Genn.) and aphids on tomato plants. Alex. Sci. Exch., 17(3): 271-276.

Shaheen, A.H. (1976). Control of the whitefly, Bemisia tabaci (Genn.) the main insect factor transmitting tomato leaf curl virus diseases. Annals Agric. Sci., Moshtohor, Egypt 6: 23-245.

Takeshi Iamoto and Kazuhiro

Komatsu, (1985). Residue determination of etofenprox in or on tomatoes treated with etofenprox 20\% EC. Japan Food Research Laboratories. Tokyo, Japan. (Rotary Report May, 1985)

Tomoda, K. (1985 a). Metabolism study of etofenprox. Metabolism in rice plants. Mitsui-Toatsu Chemicals, Inc. Tokyo, Japan.

Tomoda, K. (1985 b). Metabolism study of etofenprox. Metabolism in bean plants. Mitsui-Toatsu Chemicals, Inc. Tokyo, Japan.

Turkoglur, T. (1978). Effect of virus infestation time on yield of five tomato varieties. J. Turk. Phytopath. 7: 33-37. 
Arab Univ. J. Agric. Sci., Ain Shams Univ., Cairo, 13(3), 963 - 977, 2005

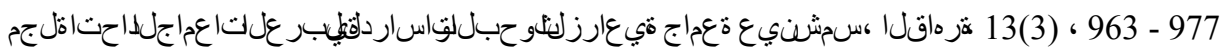
، 2005

\section{]65[}

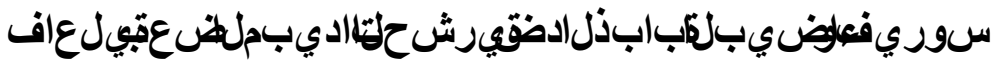

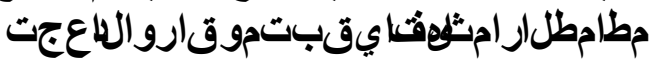

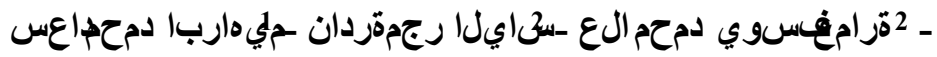

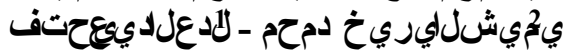

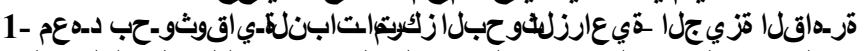

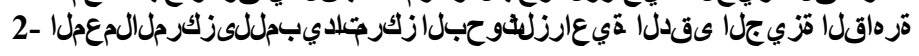

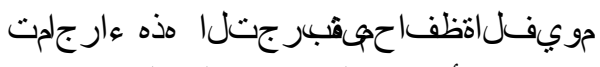

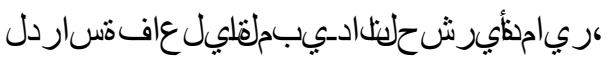

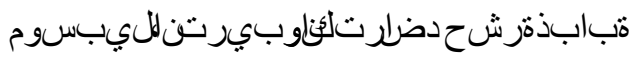

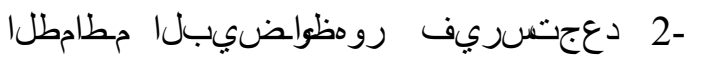

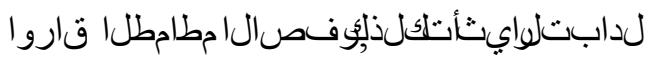

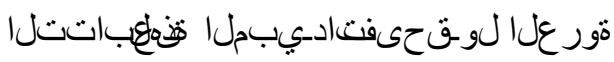

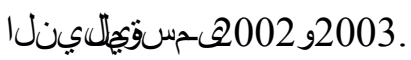

\section{ىلي المهيللايصل}

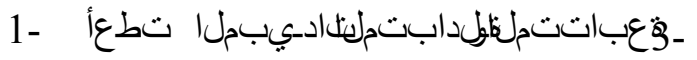

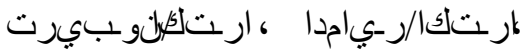

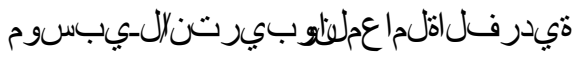

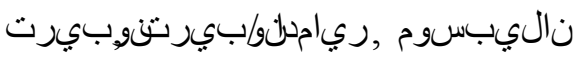

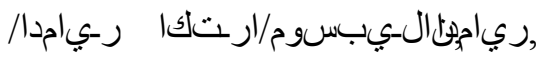

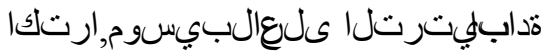

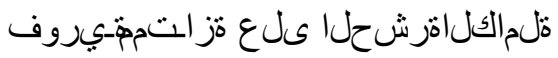

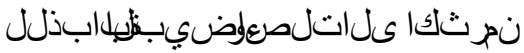

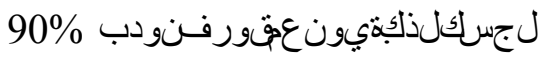

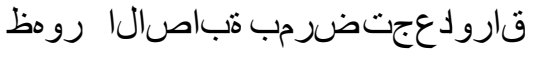

تيون عمقورفنوديوفس الال مطامطل|

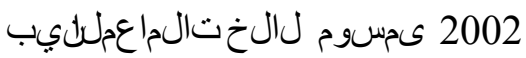
و2003.

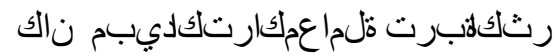

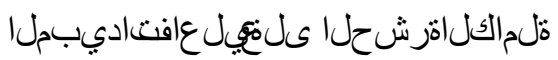

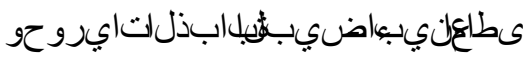

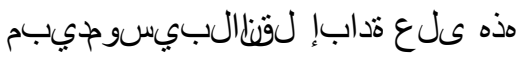

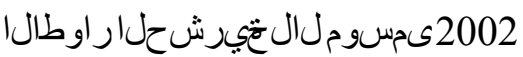
2003.

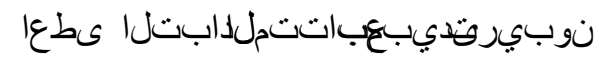

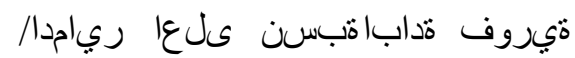
كجسوم لالخ (92.9\% و امنيبيبيترتلا ىلع 2003 و و 2002

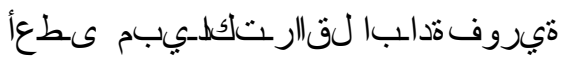
كمسوم لالخ (62.9\% $603.1 \%$ (63.

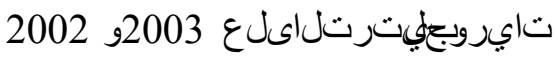
.

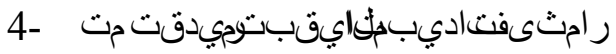

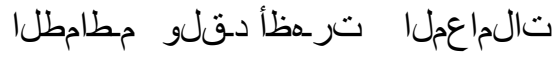

1- Plant protection Res. Institute, Agric.Res. Center, Dokki, Egypt

2- Central Agricultural Pesticides Laboratory, Dokki, Giza; Egypt

(Received May 25, 2005)

(Accepted June 13, 2005) 
Arab Univ. J. Agric. Sci., Ain Shams Univ., Cairo, 13(3), 963 - 977, 2005

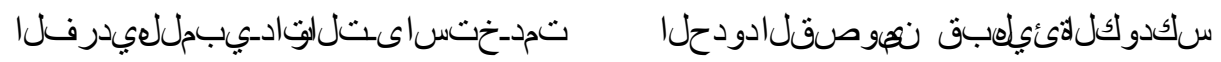

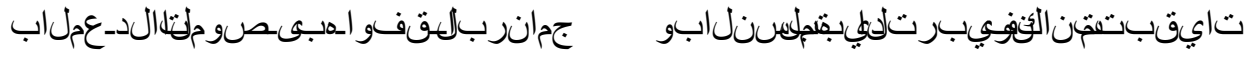

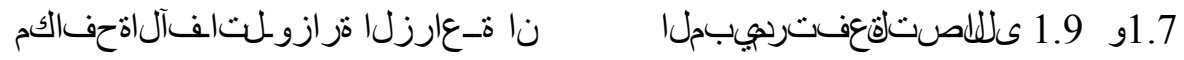

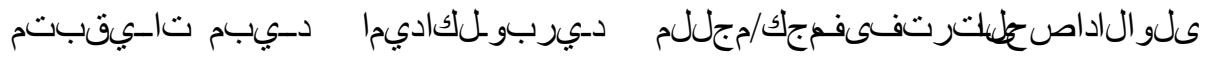

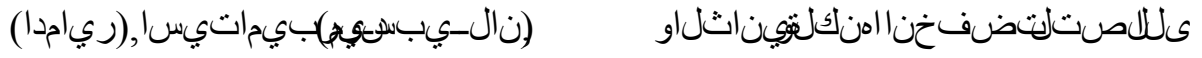

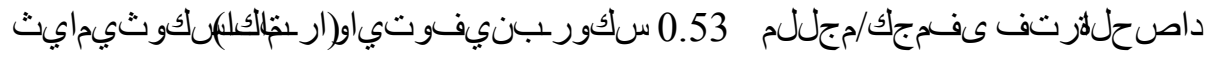

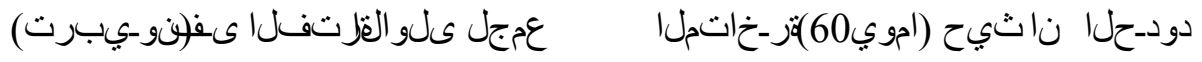

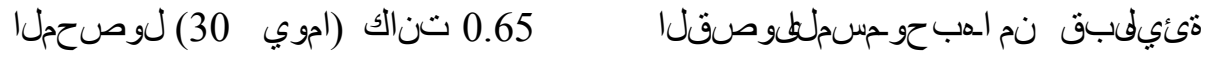

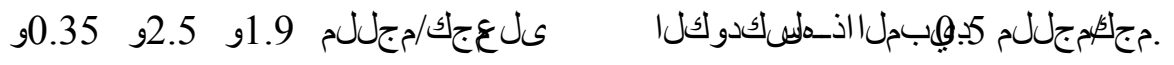

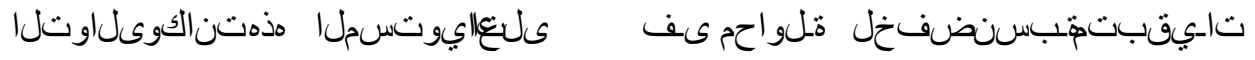

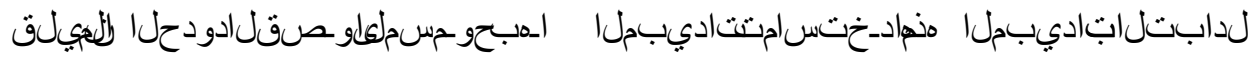

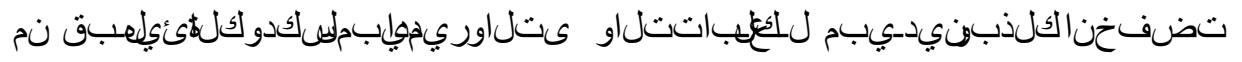

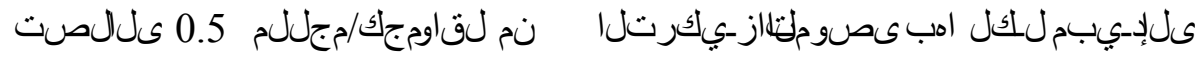

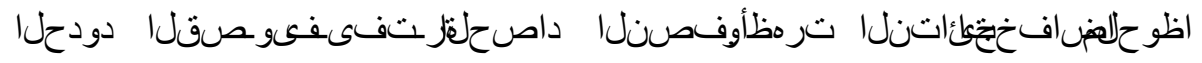

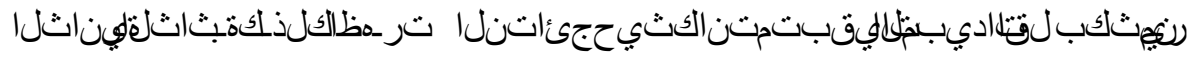

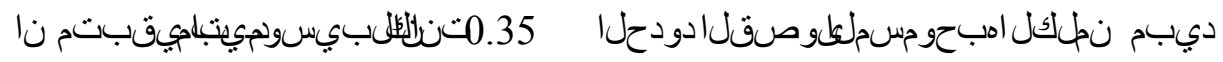

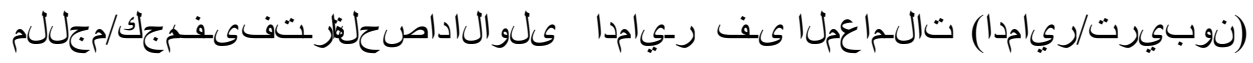

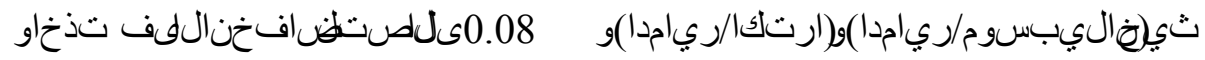

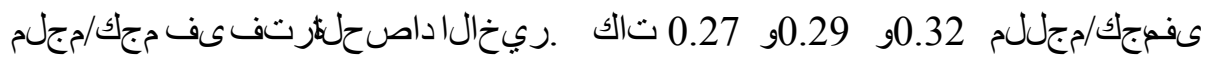

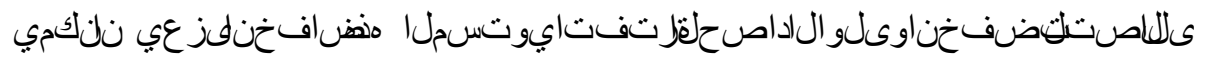

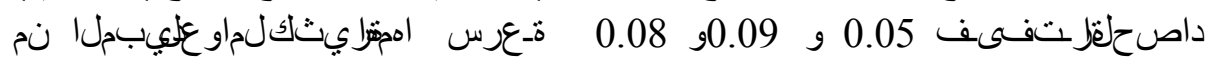

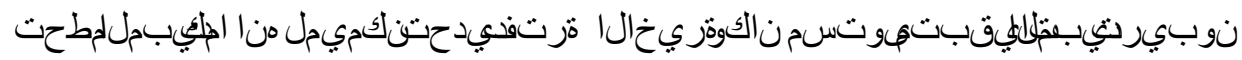

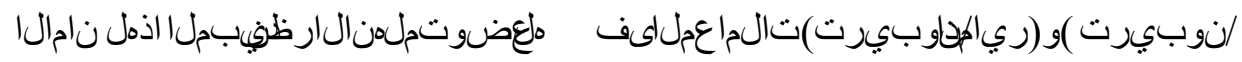

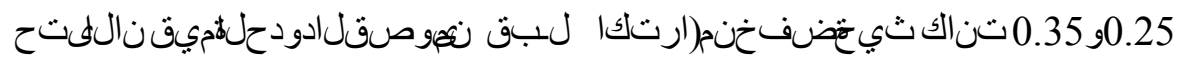

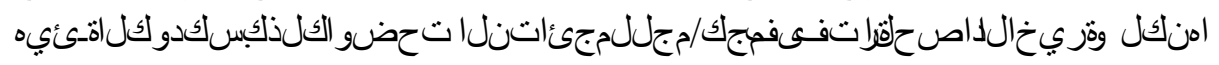

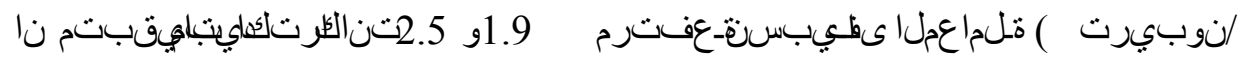

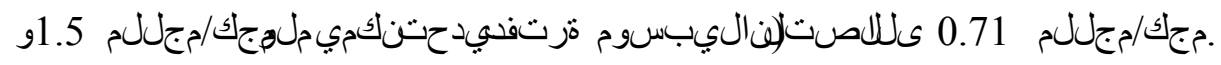
تايقبت تضافخن إثساردلا تحضوكتذك ميق دوجومدعللوص حمل عمجل نامالا

1- Plant protection Res. Institute, Agric.Res. Center, Dokki, Egypt

2- Central Agricultural Pesticides Laboratory, Dokki, Giza; Egypt

(Received May 25, 2005)

(Accepted June 13, 2005) 
Soad; Nadra; Ola; Fathy and El-Sheemy

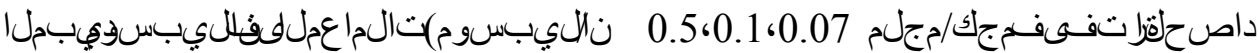

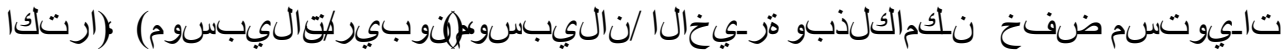

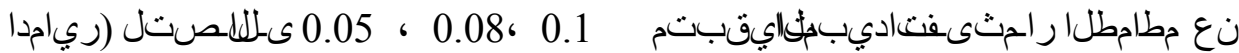

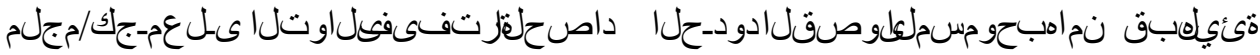

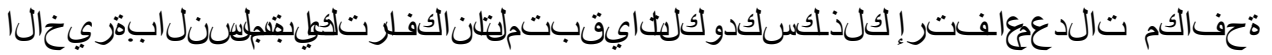

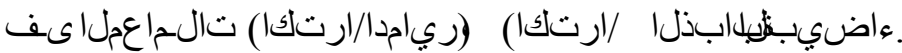

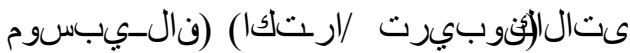

ديمحلبلبعىدنه اديز د:ألميكحت

ىلنعيز علا بيعتف دئن د.أ 